\title{
On top of a Mediterranean Massif: Climate change and conservation of orophilous moths at the southern boundary of their range (Lepidoptera: Macroheterocera)
}

\author{
STEFANO SCALERCIO \\ CRA Centro di Ricerca per l'Olivicoltura e l'Industria Olearia, Contrada Li Rocchi-Vermicelli, I-87036 Rende, Italy; \\ e-mail: stefano.scalercio@entecra.it
}

Key words. Biogeographic relict, extinction risk, global warming, species richness, sub-alpine prairies

\begin{abstract}
During the last few decades the tree line has shifted upward on Mediterranean mountains. This has resulted in a decrease in the area of the sub-alpine prairie habitat and an increase in the threat to strictly orophilous moths that occur there. This also occurred on the Pollino Massif due to the increase in temperature and decrease in rainfall in Southern Italy. We found that a number of moths present in the alpine prairie at $2000 \mathrm{~m}$ appear to be absent from similar habitats at $1500-1700 \mathrm{~m}$. Some of these species are thought to be at the lower latitude margin of their range. Among them, Pareulype berberata and Entephria flavicinctata are estimated to be the most threatened because their populations are isolated and seem to be small in size. The tops of these mountains are inhabited by specialized moth communities, which are strikingly different from those at lower altitudes on the same massif further south. The majority of the species recorded in the sub-alpine prairies studied occur most frequently and abundantly in the core area of the Pollino Massif. Species and, as a consequence, communities found at high altitudes are highly vulnerable to climate warming, and need further monitoring.
\end{abstract}

\section{INTRODUCTION}

Climate change is one of the most pervasive influences that fauna and flora are currently exposed to, as it is likely to strongly influence the distribution of species. Latitudinal and altitudinal range shifts are well known dynamic responses to new climate scenarios (Parmesan et al., 1999; Pounds et al., 1999; Konvicka et al., 2003; Hickling et al., 2006; Wilson et al., 2005, 2007; Merrill et al., 2007). Roy \& Sparks (2000) argue that the most predicted effect of climate change on butterflies is that it is likely to be positive, but this is not generally true. Whilst in the United Kingdom many species are at their northern European limit and are often constrained by low temperature, in the Mediterranean Basin these species are at their southern European limit and are constrained by high temperatures (Stefanescu et al., 2004). Animal and plant species richness is known to increase at higher altitudes and latitudes in response to climate change (Grabherr et al., 1994; Pounds et al., 1999; Wilson et al., 2005), but that there is a negative correlation between temperature and species richness at lower latitudes (Stefanescu et al., 2004), and in Northern Finland the ranges of many cooladapted species have decreased because of climate warming (Virtanen \& Neuvonen, 1999). Furthermore, the increase in diversity is mostly attributable to an increase in generalist and/or highly mobile species (Warren et al., 2001), whilst climate change could lead to the local extinction of specialist and less mobile species, and regional biodiversity loss (Boggs \& Murphy, 1997).

Species composition and biodiversity patterns on a local scale are most significantly affected by altitude (Scalercio et al., 2007). These patterns were set mainly during the last glaciation, when many northern plant and animal species established themselves in Southern Europe. At the end of this glacial period these species shifted northwards and/or upwards (Holdhaus, 1954). The threat to mountain biota in a changing world is stressed by several authors (Grabherr et al., 1994; Williams et al., 2003; Hilbert et al., 2004; Thomas et al., 2004). It is particularly serious in the Mediterranean Basin where it is recorded that an increase of $1.3^{\circ} \mathrm{C}$ in mean annual temperature associated with climate warming caused an upward shift of $212 \mathrm{~m}$ in the lower altitudinal limit of many butterflies (Wilson et al., 2005). The Fourth IPCC report predicts that the surface temperature of Mediterranean countries will increase by a further $3.0-3.5^{\circ} \mathrm{C}$ by 2100 (Intergovernmental Panel of Climate Change, 2007) strongly reducing the suitability of habitats for mountaintop-restricted species (Williams et al., 2003; Hilbert et al., 2004). In fact, altitudinal and latitudinal shift of species is often impracticable on mountains. Thus, as suggested by many authors, the extinction risk for many orophilous species strongly increases at the southern boundary of their range (Williams et al., 2003; Hilbert et al., 2004; Thomas et al., 2004; Hoyle \& James, 2005; Sekercioglu et al., 2008).

The aim of this paper was to evaluate the threat caused by climate change to mountaintop-restricted moth species (Macroheterocera) on the Pollino Massif, Italy, which is on the southernmost boundary of the distributions of these moths. We tested the assumptions that (1) high mountain habitats on the same massif, at a similar altitude and with similar vegetation, are inhabited by very similar moth communities, (2) sub-alpine prairies are inhabited 


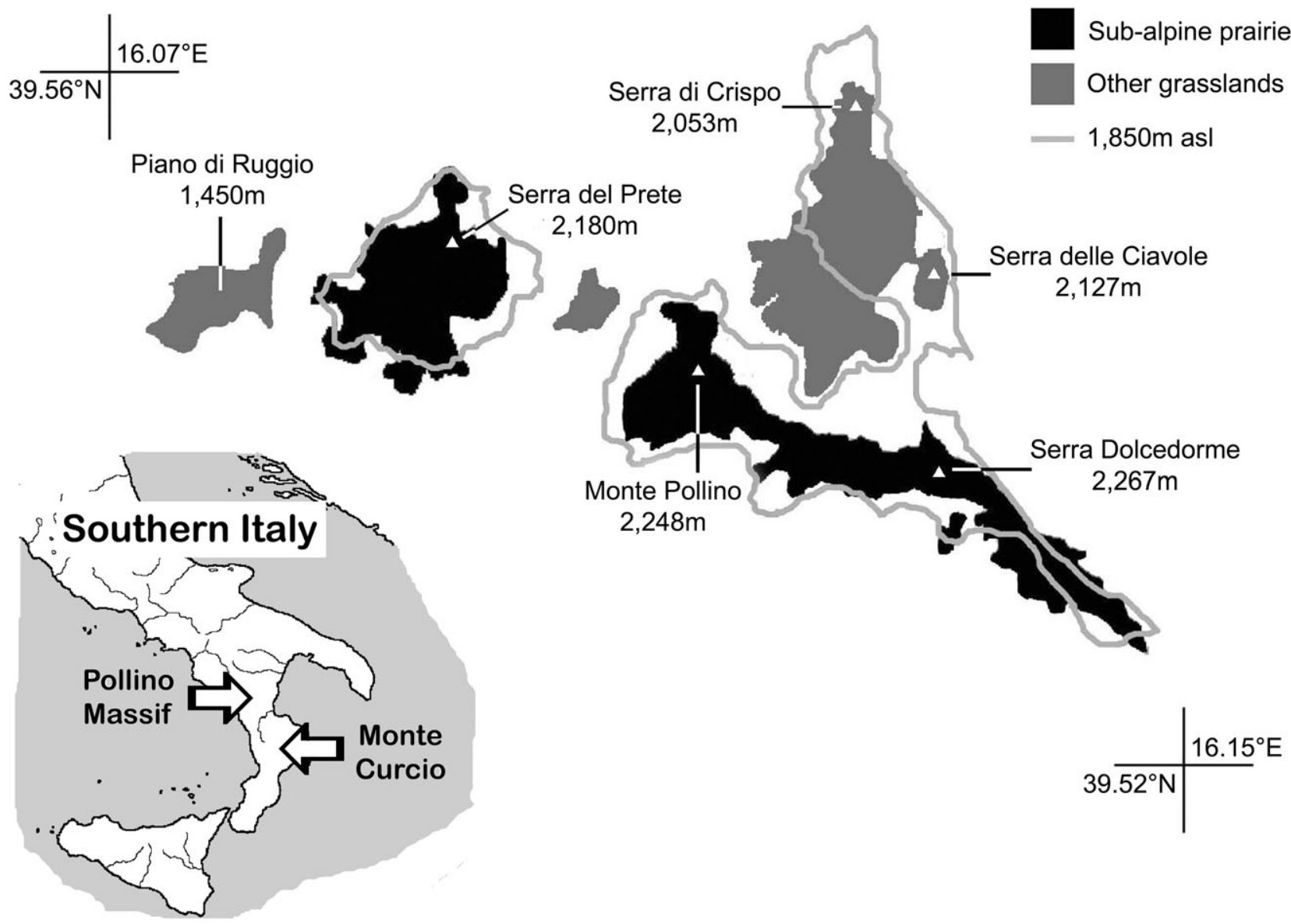

Fig. 1. Map showing the location of the study areas in Italy and the extent and location of the sub-alpine prairies and other grasslands sampled on the Pollino Massif. All the mountains higher than 2,000 $\mathrm{m}$ are indicated.

by very specialized and isolated communities, and (3) strictly orophilous species could be affected by climate change.

\section{MATERIAL AND METHODS}

\section{Study area}

The study area is located on the Pollino Massif, Southern Apennines, peninsular Italy (Fig. 1). This is the highest mountainous area in Southern Italy (Serra Dolcedorme, 2,267 m asl), with five mountains higher than $2,000 \mathrm{~m}$. The nearest massif at a similar altitude is the Meta Massif $(2,241 \mathrm{~m}$ asl) situated approx. $300 \mathrm{~km}$ to the north. The Pollino Massif, a National Park since 1993, is an important refuge for the southernmost populations of many lepidopteran species (Scalercio, 2008). It is predicted that by 2050 the Pollino Massif will be the southernmost Italian refuge for the clouded Apollo butterfly [Parnassius mnemosyne (Linnaeus)] (Araœjo \& Luoto, 2007).

The research was carried out above the tree line on Monte Pollino (hereafter MP, mean altitude of samples 2,048 $\pm 79 \mathrm{~m}$ ) and Serra del Prete (hereafter SP, mean altitude of samples $2,025 \pm 68 \mathrm{~m}$ ). A control area at a lower altitude, close to the core study area, was used to evaluate the effect of altitude on communities (clearing on Piano di Ruggio, hereafter PR, mean altitude of samples $1,536 \pm 23 \mathrm{~m}$ ). On the tops of MP and SP there are large sub-alpine prairies, the former approx. 341 ha (shared with Serra Dolcedorme) and the latter approx. 176 ha. The minimum distance between these prairies is $1.68 \mathrm{~km}$ and between the tops of MP and SP $3.05 \mathrm{~km}$. The vegetation at each study area is very homogeneous (Brandmayr et al., 2002), mainly composed of Festuca bosniaca Kumm. et Sendtn with an abundance of Sesleria nitida Ten. on the slopes of the southernmost part of SP. According to Avena \& Bruno (1975), the vegetation can be classified as Seslerio-Xerobromenion apenninum. PR is a large clearing with low vegetation characterised by Meum athamanticum Jacq. All sampled grasslands were bordered by forests dominated by European beech (Fagus sylvatica L.).

Another sample included in the analysis was that of a moth community in a meadow surrounded by a forest of European beech (Scalercio et al., 2008) on the Sila Massif (Monte Curcio, $1690 \mathrm{~m}$, hereafter MC), on the nearest mountainous area south of the Pollino Massif.

\section{Changes in regional climate}

Recently there have been changes in the climate in Southern Italy. Brunetti et al. (2006) found that all Italian regions became warmer and drier during the period 1865-2003. More evident changes occurred in Southern Italy, where rain fall decreased by $10 \%$ and the mean minimum temperatures increased by $1.3^{\circ} \mathrm{C}$ relative to the mean for 1961-1990. Winter and spring mean temperatures increased by $1.0^{\circ} \mathrm{C}$, more than the increase in autumn $\left(+0.9^{\circ} \mathrm{C}\right)$ but less than that in summer $\left(+1.2^{\circ} \mathrm{C}\right)$. On the other hand, spring rainfall decreased by $20 \%$, more than the decrease in summer $(-13 \%)$, but there were no significant decreases in winter and autumn rainfall. Hence the hottest season has become warmer and there has been an increase in temperature and reduction in precipitation throughout the year. On the Pollino Massif indirect evidence of these changes are provided by old pictures (Tamanini, 1961) showing an appre- 


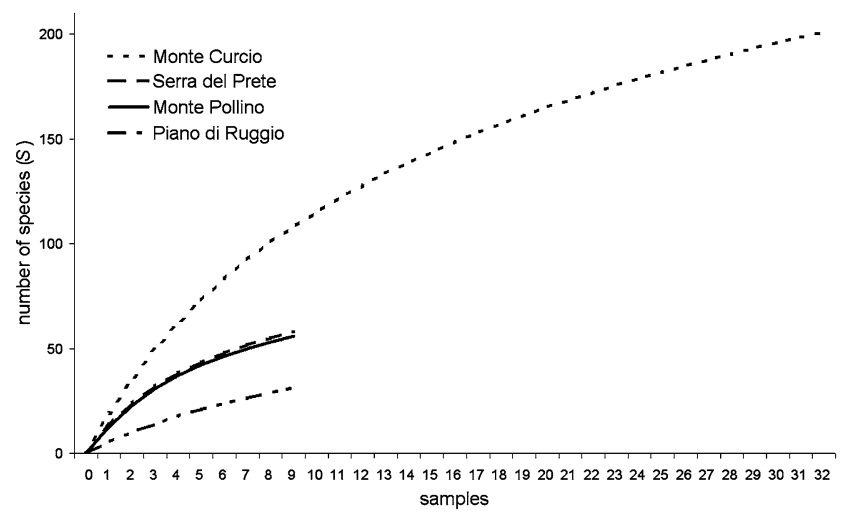

Fig. 2. Species accumulation curves of sample-based rarefaction (Mao Tau) for the moth assemblages.

ciable upward shift of European beech forests. Similar findings are documented also for other Mediterranean areas (Peñuelas et al., 2007).

\section{Sampling method}

Moths were trapped on five occasions using six portable light traps, two per site, operating simultaneously over a total period of 30 nights. Each period of trapping was separated by at least nine days. The trapping periods coincided with those when orophilous moths are most active (late June - late September 2004), on moonless nights or when the moon was waxing. The effect of climatic differences between the sites was avoided by simultaneously running light traps at all three sites. In order to collect only specimens from the area immediately surrounding the traps, low power lamps were utilised (15 W UV fluorescent tube) and to reduce their attractive radius they were positioned $60 \mathrm{~cm}$ above ground level (Baker \& Sadovy, 1978). Traps were provided with crepuscular switches and located at a minimum distance of $50 \mathrm{~m}$ from the edge of the grasslands. In order to minimise the site-effect, a "100 square" grid was superimposed on aerial photographs of the study sites and the trap locations were changed every night by randomly choosing two squares per site, at least $100 \mathrm{~m}$ from other squares used on the same night. No square was chosen more than once.

Before opening the traps at sunrise the area around each trap was searched for moths that were attracted but not caught by the traps. Trapped individuals were anaesthetised during the night by means of a dispenser containing minced Prunus laurocerasus L. (Rosaceae) leaves that released a small amount of cyanihydric acid. Before opening the traps drops of chloroform were introduced into each trap and after a few seconds the number of individuals of each species recorded. Only a few voucher specimens were retained and the remaining specimens released. Specimens belonging to taxonomically critical species were identified by morphological analysis of their genitalia.

\section{Data analysis}

Although there are many indices of diversity, species richness is the most widely utilised and easily understandable measure. The effectiveness of the sampling was evaluated by using software EstimateS 7.5 (Colwell, 2005) and the "total" species richness of a sample and the rate of species accumulation per individual at the final visit (Gotelli \& Colwell, 2001). Abundance-based (ACE, Chao2) and incidence-based (ICE, Chao1, Jack1, Jack2, Bootstrap) species richness estimators were used in order to avoid biases due to the use of only one estimator. Before running the analysis, the results were submitted to 100 randomizations, which provided a mean among runs and a standard deviation for all computed estimators. The

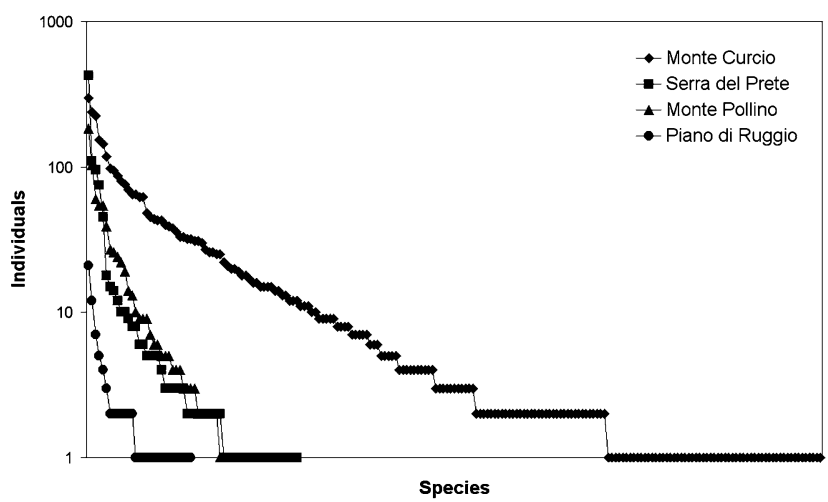

Fig. 3. Frequency distribution of species plotted on a logarithmic scale for each of the sites studied.

running of randomizations allowed us to conduct a species richness comparison by the means of species accumulation curves of a sample-based rarefaction (Mao Tau).

Of the similarity indices computed by EstimateS 7.5 the qualitative Jaccard Classic $\left(J_{\mathrm{c}}\right)$ and quantitative Morisita-Horn $(M H)$ indices were selected (Colwell, 2005). Quantitative indices are known to be the most satisfactory (Magurran, 1988) but qualitative indices are less influenced by sample size and easier to interpret. These indices equal 1 when two sets of species / individuals are identical and 0 if they are completely different. These indices were used to evaluate the differences between communities.

The habitat preferences of adults and their altitudinal distribution, based on unpublished regional records and literature on the Calabrian moth fauna (for a review see Parenzan \& Porcelli, 2006), were analysed in order to determine whether the moths were habitat specialists. Habitat preferences were designated as either: (i) grassland, prefer herbaceous habitats; (ii) woodland, prefer forests; (iii) ecotonal, prefer clearings and forest margins, or (iv) ubiquitous, have no preferred habitat. Their occurrence at high altitudes is the main natural factor leading to fragmented and isolated populations (Boggs \& Murphy, 1997). Based on their preference for particular altitudes the species were grouped as either: (1) strictly orophilous, found in Calabria only above $1000 \mathrm{~m}$; (2) orophilous, found only above $400 \mathrm{~m}$; or (3) widespread, without an altitudinal preference.

Particular attention was paid to species at the southern boundary of their range because their status is likely to be a good early indicator of climate change (New, 2004). These are the species that are currently not found south of the Pollino Massif in Italy (including Sicily) or in North Africa. The diversity and abundance of these species was determined with particular emphasis on the differences between the MP and SP communities. The abundance value used was dominance expressed as $n \mathrm{i} / N$, where $n \mathrm{i}$ equals the number of individuals belonging to species $i, N$ equals the number of individuals of all species recorded within a given community.

Only MC data collected during the same months were used in the comparisons.

\section{RESULTS}

We caught 1,804 individuals belonging to 85 species (Appendix 1), representing approx. $76 \%$ of the moth fauna predicted to be present by using the mean of the diversity estimators and $10 \%$ of the regional fauna. Moths of the sub-alpine prairies and Monte Curcio were sampled equally. In fact, for SP and MP it was estimated that 
Appendix 1. List of species caught at each study site: Serra del Prete, SP; Monte Pollino, MP; Piano di Ruggio, PR; Monte Curcio, MC. For each species the number of individuals caught and their altitudinal and habitat preferences are recorded. For MC only data for species that were also caught on the Pollino Massif are reported. For the complete list of MC species see Scalercio et al. (2008). Nomenclature follows Parenzan \& Porcelli (2006). Species are ordered according to altitudinal preference and decreasing abundance.

\begin{tabular}{|c|c|c|c|c|c|c|}
\hline Species & SP & MP & PR & $\mathrm{MC}$ & Altitude & Habitat \\
\hline Agrotis cinerea & 428 & 183 & 0 & 12 & strictly orophilous & grassland \\
\hline Rhopalognophos glaucinaria ${ }^{\text {a }}$ & 110 & 103 & 4 & 0 & strictly orophilous & grassland \\
\hline Hyphoraia testudinaria & 96 & 39 & 12 & 0 & strictly orophilous & grassland \\
\hline Hadula odontites & 75 & 54 & 0 & 0 & strictly orophilous & grassland \\
\hline Tholera decimalis & 45 & 5 & 21 & 2 & strictly orophilous & grassland \\
\hline Xestia ashworthii a & 8 & 60 & 0 & 0 & strictly orophilous & grassland \\
\hline Hada plebeja & 10 & 26 & 0 & 104 & strictly orophilous & grassland \\
\hline Epipsilia grisescens ${ }^{\text {a }}$ & 4 & 22 & 0 & 0 & strictly orophilous & grassland \\
\hline Setina irrorella ${ }^{\text {a }}$ & 0 & 24 & 0 & 0 & strictly orophilous & grassland \\
\hline Mniotype adusta ${ }^{\text {a }}$ & 5 & 13 & 0 & 0 & strictly orophilous & grassland \\
\hline Albocosta musiva $^{\text {a }}$ & 9 & 9 & 0 & 0 & strictly orophilous & grassland \\
\hline Hadena caesia ${ }^{\text {a }}$ & 5 & 9 & 0 & 0 & strictly orophilous & grassland \\
\hline Malacosoma castrensis & 6 & 0 & 5 & 0 & strictly orophilous & grassland \\
\hline Dyscia raunaria $^{\text {a }}$ & 5 & 3 & 0 & 0 & strictly orophilous & grassland \\
\hline Hadena albimacula & 3 & 3 & 0 & 3 & strictly orophilous & ecotonal \\
\hline Abromias platinea & 1 & 4 & 0 & 0 & strictly orophilous & ecotonal \\
\hline Chersotis multangula & 3 & 1 & 0 & 0 & strictly orophilous & grassland \\
\hline Episema tersa & 0 & 3 & 1 & 0 & strictly orophilous & ecotonal \\
\hline Noctua interposita & 2 & 0 & 1 & 2 & strictly orophilous & grassland \\
\hline Eupithecia pimpinellata & 2 & 1 & 0 & 0 & strictly orophilous & ecotonal \\
\hline Polymixis xanthomista & 0 & 0 & 3 & 0 & strictly orophilous & ecotonal \\
\hline Chersotis rectangula & 2 & 1 & 0 & 8 & strictly orophilous & grassland \\
\hline Watsonalla cultraria & 1 & 1 & 0 & 61 & strictly orophilous & woodland \\
\hline Eupithecia linariata & 2 & 0 & 0 & 1 & strictly orophilous & ecotonal \\
\hline Entephria flavicinctata ${ }^{\text {a }}$ & 0 & 2 & 0 & 0 & strictly orophilous & grassland \\
\hline Pareulype berberata ${ }^{\text {a }}$ & 0 & 2 & 0 & 0 & strictly orophilous & ecotonal \\
\hline Mniotype anilis & 1 & 1 & 0 & 0 & strictly orophilous & ecotonal \\
\hline Rhyacia lucipeta & 1 & 1 & 0 & 0 & strictly orophilous & ecotonal \\
\hline Agrotis clavis & 1 & 1 & 0 & 70 & strictly orophilous & grassland \\
\hline Antitype jonis a & 1 & 0 & 0 & 0 & strictly orophilous & grassland \\
\hline Sideridis lampra ${ }^{\mathrm{a}}$ & 1 & 0 & 0 & 0 & strictly orophilous & grassland \\
\hline Euphyia frustata & 1 & 0 & 0 & 0 & strictly orophilous & ecotonal \\
\hline Scotopteryx bipunctaria & 1 & 0 & 0 & 4 & strictly orophilous & ecotonal \\
\hline Noctua janthe & 1 & 0 & 0 & 4 & strictly orophilous & ecotonal \\
\hline Arctia caja & 0 & 0 & 1 & 10 & strictly orophilous & ecotonal \\
\hline Hadena luteocincta & 14 & 54 & 0 & 2 & orophilous & grassland \\
\hline Watsonarctia deserta & 18 & 19 & 0 & 0 & orophilous & grassland \\
\hline Pachetra sagittigera & 6 & 14 & 0 & 20 & orophilous & grassland \\
\hline Amphipyra tragopoginis & 10 & 6 & 1 & 1 & orophilous & ecotonal \\
\hline Chersotis margaritacea & 3 & 10 & 1 & 1 & orophilous & grassland \\
\hline Macrothylacia rubi & 5 & 4 & 0 & 0 & orophilous & ecotonal \\
\hline Scotopteryx moeniata & 1 & 0 & 1 & 0 & orophilous & grassland \\
\hline Acronicta euphorbiae & 1 & 1 & 0 & 0 & orophilous & grassland \\
\hline Hoplodrina octogenaria & 2 & 0 & 0 & 25 & orophilous & ecotonal \\
\hline Aporophyla lutulenta & 0 & 0 & 2 & 0 & orophilous & ecotonal \\
\hline Ammoconia caecimacula & 0 & 0 & 2 & 0 & orophilous & ecotonal \\
\hline Noctua fimbriata & 2 & 0 & 0 & 7 & orophilous & ubiquitous \\
\hline Yigoga nigrescens & 1 & 0 & 1 & 0 & orophilous & grassland \\
\hline Eilema complana & 0 & 0 & 2 & 15 & orophilous & ecotonal \\
\hline Rhodostrophia vibicaria & 1 & 0 & 0 & 2 & orophilous & ecotonal \\
\hline
\end{tabular}

${ }^{a}$ Species at the southern boundary of their distribution on the Pollino Massif. 
APPENDIX 1 (continued).

\begin{tabular}{|c|c|c|c|c|c|c|}
\hline Species & SP & MP & PR & $\mathrm{MC}$ & Altitude & Habitat \\
\hline Pennithera firmata & 0 & 0 & 1 & 0 & orophilous & woodland \\
\hline Cryphia raptricula & 0 & 1 & 0 & 0 & orophilous & ecotonal \\
\hline Colostygia pectinataria & 0 & 1 & 0 & 16 & orophilous & ecotonal \\
\hline Catocala dilecta & 0 & 1 & 0 & 0 & orophilous & woodland \\
\hline Xanthia togata & 0 & 0 & 1 & 0 & orophilous & ecotonal \\
\hline Noctua pronuba & 15 & 27 & 1 & 25 & widespread & ubiquitous \\
\hline Epirrhoe galiata & 8 & 9 & 2 & 56 & widespread & ecotonal \\
\hline Noctua comes & 12 & 5 & 0 & 5 & widespread & ubiquitous \\
\hline Paradrina selini & 3 & 7 & 0 & 0 & widespread & grassland \\
\hline Hadena compta & 2 & 6 & 0 & 0 & widespread & grassland \\
\hline Agrotis bigramma & 1 & 0 & 7 & 3 & widespread & grassland \\
\hline Abromias monoglypha & 3 & 2 & 1 & 80 & widespread & ubiquitous \\
\hline Triodia sylvina & 0 & 5 & 0 & 3 & widespread & ecotonal \\
\hline Hyles livornica & 2 & 2 & 1 & 1 & widespread & ubiquitous \\
\hline Peridroma saucia & 1 & 4 & 0 & 3 & widespread & ubiquitous \\
\hline Agrotis ipsilon & 3 & 2 & 0 & 2 & widespread & ubiquitous \\
\hline Eupithecia semigraphata & 1 & 3 & 0 & 2 & widespread & ecotonal \\
\hline Agrotis segetum & 2 & 1 & 1 & 10 & widespread & ubiquitous \\
\hline Lemonia taraxaci & 0 & 0 & 2 & 5 & widespread & ecotonal \\
\hline Campaea margaritaria & 0 & 0 & 2 & 32 & widespread & woodland \\
\hline Scopula marginepunctata & 0 & 1 & 1 & 0 & widespread & ubiquitous \\
\hline Nebula salicata & 1 & 1 & 0 & 0 & widespread & ubiquitous \\
\hline Autographa gamma & 0 & 2 & 0 & 0 & widespread & ubiquitous \\
\hline Mythimna vitellina & 1 & 1 & 0 & 3 & widespread & ubiquitous \\
\hline Noctua janthina & 2 & 0 & 0 & 0 & widespread & ubiquitous \\
\hline Agrotis exclamationis & 0 & 0 & 2 & 9 & widespread & ubiquitous \\
\hline Hyles euphorbiae & 0 & 1 & 0 & 0 & widespread & ubiquitous \\
\hline Camptogramma bilineata & 0 & 0 & 1 & 0 & widespread & ecotonal \\
\hline Gymnoscelis rufifasciata & 0 & 0 & 1 & 57 & widespread & ubiquitous \\
\hline Pyrois effusa & 0 & 1 & 0 & 0 & widespread & ecotonal \\
\hline Mesapamea secalis & 1 & 0 & 0 & 3 & widespread & ubiquitous \\
\hline Mythimna ferrago & 1 & 0 & 0 & 4 & widespread & ubiquitous \\
\hline Xestia c-nigrum & 0 & 1 & 0 & 9 & widespread & ubiquitous \\
\hline Colocasia coryli & 0 & 1 & 0 & 44 & widespread & woodland \\
\hline Callimorpha dominula & 0 & 1 & 0 & 0 & widespread & ecotonal \\
\hline
\end{tabular}

${ }^{a}$ Species at the southern boundary of their distribution on the Pollino Massif.

$71.9 \%$ and $68.4 \%$ of species were recorded and the final rate of accumulation was 0.027 and 0.034 , respectively, i.e. more than a further 30 individuals needed to be collected in order to add another species; for MC the values were $73.6 \%$ of the species and final rate of accumulation was 0.044 . However, PR was clearly not as well sampled as only $55.7 \%$ of species were recorded and the final rate of accumulation was 0.244 , i.e. only a further four individuals needed to be collected to add a further species. As a consequence, MC / MP and MC / SP can be compared with confidence but not PR / MP and PR / SP, however, because the communities were sampled equally the PR community is clearly species poor (Fig. 2). Frequency distributions of the species at the three sites differed with the MC's curve relatively more log normal-shaped than those for MP, SP and PR, which are more log seriesshaped (Fig. 3). This may be because a more powerful light source was used and/or the proximity of forests at MC.
Similarity indices indicated that MP and SP are the most similar and very different from PR and MC (Table 1 ), confirming the uniqueness of sub-alpine moth communities. That the comparisons PR/MP, PR/SP, MC/MP and $\mathrm{MC} / \mathrm{SP}$ yielded low similarity values is not unexpected, but that for MC/PR is unexpected and may be due to the geographical isolation of the Sila Massif and the different method of sampling at MC.

MP and SP communities are dominated by Agrotis cinerea $(23.9 \%$ and $44.9 \%$ of individuals, respectively), a univoltine species that flies early in the year. This species was probably not collected at PR because it flies earlier at lower altitudes. Merrill et al. (2007) estimated that Aporia crataegi $\mathrm{L}$. flies $30-40$ days later per $1 \mathrm{~km}$ increase in altitude. Thus, it is likely that $A$. cinerea would have been caught at PR if sampling there had started 15-20 days earlier. The results for MC seem to confirm this as $A$. cinerea was recorded there 10-days earlier than at SP and MP. A similar explanation could hold for the absence of 
TABLE 1. Similarity values of between site comparisons.

\begin{tabular}{cccc}
\hline First sample & Second sample & Jaccard classic & Bray-Curtis \\
\hline SP & MP & 0.562 & 0.623 \\
SP & PR & 0.208 & 0.104 \\
SP & MC & 0.180 & 0.079 \\
MP & PR & 0.164 & 0.073 \\
MP & MC & 0.142 & 0.112 \\
PR & MC & 0.101 & 0.033 \\
\hline
\end{tabular}

Hadula odontites, Watsonarctia deserta, Hada plebeja, Pachetra sagittigera, Hadena caesia and Macrothylacia rubi among the moths caught at PR. Rhopalognophos glaucinaria (11.5\% of individuals) together with $A$. cinerea make up half of all the moths caught at SP, whereas at MP, in addition to A. cinerea, it is necessary to include the catches of $R$. glaucinaria $(13.5 \%)$, Xestia ashworthii (7.8\%) and Hadena luteocincta (7.1\%).

The small attractive radius of traps and their location within the grassland areas resulted in them only sampling the communities that resided within the grasslands (Table 2). All the communities were largely composed of species linked to grassland habitats, with only very few woodland species recorded. In addition to the similar percentages of the same species an appreciable increase in non-grassland individuals were recorded at PR. This may be due to the different sampling method used there (more powerful light source located close to a beech forest). At MC a higher percentage of woodland and lower percentage of grassland species was recorded.

Strictly orophilous moths were very abundant and dominated the SP and MP communities (Table 2). These species were less abundant at PR where widespread species were more abundant than at SP. Altitudinal preferences of the species at MC were more similar to those at PR than SP or MP, where a further decrease in strictly orophilous and increase in widespread species were recorded.

The species caught at MP and SP were more specialized than those caught at MC. Among the 34 strictly orophilous species caught at MP and SP only 11 were also caught on Monte Curcio and only Agrotis cinerea, Tholera decimalis and Hada plebeja were common to both massifs (Appendix 1).
The twelve strictly orophilous species collected in this study, which are at the southern boundary of their range, are listed in table 3 . Only the common $R$. glaucinaria occurs at PR while at MP and SP there is a very similar diversity of these priority species. Nonetheless, they were always more abundant at MP, except for Dyscia raunaria, Antitype jonis and Sideridis lampra. Of the four species on the Pollino Massif never found at lower altitudes, only Epipsilia grisescens was found at both MP and SP, while Entephria flavicinctata, Pareulype berberata and Setina irrorella were found only at MP.

\section{DISCUSSION}

\section{Individual species perspectives}

For conservation, the small populations at the border of a species distribution are more important because they are genetically very different from the core population (Zakharov \& Hellmann, 2008). The loss of these populations would result in the loss of within-species diversity. Therefore, it can be argued that Pareulype berberata, Entephria flavicinctata, Setina irrorella, Epipsilia grisescens and Xestia ashworthii, which make up 5.9\% of the moth species collected in this study, are in need of conservation because they are representatives of a cooladapted fauna currently restricted to high altitudes in Southern Europe. If the predicted change in climate occurs these species could be extinct in a few decades and their southern range much further to the north than currently.

$P$. berberata is monophagous on Berberis vulgaris L. but only the congeneric $B$. aetnensis Presl. is present on the highest rocky slopes of the Pollino Massif (L. Bernardo, pers. comm.). E. flavicinctata feeds on various species of saxifrage (Saxifraga) and stonecrop (Sedum). The populations of these two species found on Monte Pollino are very small and very isolated from the nearest populations, which are only recorded at scattered mountainous sites in Central Italy (Racheli et al., 1978; Raineri et al., 1992). P. berberata and E. flavicinctata belong to the family Geometridae, which includes good bioindicator species because they are bad fliers and do not move far from where they emerge as adults (Usher \& Keiller, 1998; Kitching et al., 2000; Hausmann, 2002). The mono-

TABLE 2. Percentages of the species and individuals (in parenthesis) of the moths that have particular habitat preferences and altitudinal distributions at each of the study sites. The percentages were obtained by analysing each community separately and that on the Pollino Massif as a unique sample.

\begin{tabular}{lccccc}
\hline & Serra del Prete & Monte Pollino & Piano di Ruggio & Pollino Massif & Monte Curcio \\
\hline Habitat & & & & & \\
$\quad$ grassland & $50.0(90.9)$ & $42.9(87.1)$ & $31.0(64.6)$ & $36.5(88.1)$ & $15.2(23.0)$ \\
$\quad$ ecotonal & $25.9(4.2)$ & $28.6(6.0)$ & $37.9(22.0)$ & $35.3(5.7)$ & $44.8(30.7)$ \\
$\quad$ woodland & $1.7(0.1)$ & $5.4(0.4)$ & $6.9(3.7)$ & $5.9(0.4)$ & $16.6(26.4)$ \\
$\quad$ ubiquitous & $22.4(4.8)$ & $23.2(6.5)$ & $24.1(9.8)$ & $22.4(5.8)$ & $23.4(19.9)$ \\
Altitude & & & & \\
$\quad$ strictly orophilous & $50.0(87.1)$ & $45.3(74.7)$ & $27.6(58.5)$ & $42.4(80.6)$ & $24.8(30.6)$ \\
$\quad$ orophilous & $20.7(6.7)$ & $17.2(14.5)$ & $30.0(15.5)$ & $23.5(10.4)$ & $24.8(17.2)$ \\
$\quad$ widespread & $29.3(6.2)$ & $37.5(10.8)$ & $42.4(26.0)$ & $34.1(9.0)$ & $50.3(52.2)$ \\
Number of species & 58 & 56 & 28 & 85 & 145 \\
\hline
\end{tabular}


TABLE 3. List and dominance of the strictly orophilous species that are at the southernmost boundary of their distribution on the Pollino Massif. Nomenclature follows Parenzan \& Porcelli (2006).

\begin{tabular}{lcccc}
\hline Species & Serra del Prete & Monte Pollino & Piano di Ruggio & Monte Curcio \\
\hline Rhopalognophos glaucinaria & 0.115 & 0.135 & 0.049 & - \\
Xestia ashworthii & 0.008 & 0.078 & - & - \\
${ }^{a}$ Epipsilia grisescens & 0.004 & 0.029 & - & - \\
a Setina irrorella & - & 0.031 & - & - \\
Mniotype adusta & 0.005 & 0.017 & - & - \\
Albocosta musiva & 0.009 & 0.012 & - & - \\
Hadena caesia & 0.005 & 0.012 & - & - \\
Dyscia raunaria & 0.005 & 0.004 & - & - \\
${ }^{a}$ Entephria flavicinctata & - & 0.003 & - & - \\
${ }^{a}$ Pareulype berberata & - & 0.003 & - & - \\
Antitype jonis & 0.001 & - & - & - \\
Sideridis lampra & 0.001 & - & & - \\
\hline
\end{tabular}

${ }^{a}$ not recorded at lower altitudes on the Pollino Massif in previous publications.

phagy and oligophagy, low dispersal ability, small population size and isolation of these species strongly increase the threat they are exposed to on the Pollino Massif. In fact, the range of these moths is constrained by climatic and biotic parameters, which act concurrently to increase their risk of extinction (Araœjo \& Luoto, 2007). Furthermore, E. flavicinctata is listed as threatened in Finland as consequence of global warming shrinking its habitat and because its northward movement is limited by the Arctic Ocean (Virtanen \& Neuvonen, 1999).

Xestia ashworthii was recorded from below the tree line on the Pollino Massif (Parenzan, 1979) 30 years ago but not recorded there again since then. Rhopalognophos glaucinaria is reported from many southern Italian regions and Sicily, but is certainly present only on Monte Sirino (A. Hausmann, pers. comm.) and the Pollino Massif in peninsular Italy, and more than 60 years have passed since the last record from Sicily (Parenzan \& Porcelli, 2006).

Although evolutionary responses can mitigate the risk of extinction (Skelly et al., 2007) many of the threatened species on the Pollino Massif have only one generation per year and their populations are probably too small. This could strongly reduce the level of genetic variation in their populations and consequently the likelihood of any kind of adaptation to changes in climate (Burger \& Lynch, 1995).

\section{Community perspective}

There are more highly differentiated moth communities on Monte Pollino and Serra del Prete than on the nearest southern massif. Strictly orophilous species at the southern boundary of their ranges are more frequent and abundant on Monte Pollino than on Serra del Prete. This may be attributed to the areas of suitable habitat and hence island biogeography parameters of area and connectivity of the habitats above the timberline. The metapopulation structures (Hanski \& Ovaskainen, 2000) on Monte Pollino are likely to be more complex than on Serra del Prete, because the former is situated in the centre of the mountainous area of the Pollino Massif while the latter is more isolated (Fig. 1).
Climate warming increases diversity at high altitudes (Wilson et al., 2007), where an increasing competition between high altitude and low altitude species is expected as temperatures increase in Mediterranean countries (Intergovernmental Panel of Climate Change, 2007). As a consequence, the upward shift in the range of low altitude species will strongly increase the risk of extinction of species specialized to live at high altitudes.

\section{Habitat perspective}

Although no data are available for the study area, climatic data for Southern Italy (Brunetti et al., 2006) and the upward shift of European beech forests, confirmed that a regional warming has occurred over the last few decades. One of the greatest threats posed to sub-alpine prairies by climate change is the upward shift of the tree line in Mediterranean countries (Peñuelas et al., 2007), which will decrease the area of prairie and ultimately result in the disappearance of this habitat and the related biota. Old pictures of the Pollino Massif indicate that this phenomenon is mitigated by sub-vertical rocky slopes, which slow down the upward shift of European beech forest (see Tamanini, 1961). The insular character of subalpine prairies will increase as temperatures rise in the coming decades (Intergovernmental Panel of Climate Change, 2007). Habitat fragmentation will make it difficult for the species to reach new climatically suitable areas (Thomas et al., 2004). Our results are in agreement with those of Usher \& Keiller (1998), who found, in the case of farm woodlands, that large areas of woodland are more valuable for the long-term conservation of moth diversity than fragmented woodlands. In fact, the largest area of prairie on Monte Pollino has the highest diversity of specialist (interior) species, and is thus worthy of conservation priority. Furthermore, a large patch is likely to include within-habitat differentiations that provide suitable micro-habitats for specialist species to use to escape the negative effects of climate change (Weiss et al., 1988). 


\section{CONCLUSIONS}

The biodiversity of Mediterranean areas of Europe will be impoverished by climate change because the predicted extinction rate is higher than the colonization rate. Populations of many cold-adapted species, which are scattered along the southern borders of their distributions, often restricted to high altitude prairies where the effects of climate change will be exacerbated by the absence of shelter against high temperature and drought provided by forest, are likely to become extinct. The Mediterranean mountains are very important refuges often protected by being incorporated into national parks. Since these high altitude prairies are still largely intact their biodiversity is often assumed to be secure, but because of the predicted climate change, in situ conservation strategies will only delay local species extinction.

ACKNOWLEDGEMENTS. M.G. Greco and M. Russo assisted with fieldwork. A. Hausmann, two anonymous referees and $\mathrm{M}$. Konvička made helpful comments on the text. Carl E. Jones and Alessandro Scalercio edited the English of the manuscript. A. Hausmann, P. Parenzan and A. Zilli provided literature and validated our species determination. Access and research permits were provided by the Pollino National Park. This work was funded by the Museo di Storia Naturale della Calabria e Orto Botanico, Italy, president P. Brandmayr.

\section{REFERENCES}

AraúJo M.B. \& LuOTo M. 2007: The importance of biotic interactions for modeling species distributions under climate change. Global Ecol. Biogeog. 16: 743-753.

Avena G. \& Bruno F. 1975: Lineamenti della vegetazione del Massiccio del Pollino (Appennino calabro-lucano). Nota Fitosociol. 10: 131-158.

BAKER R.R. \& SAdOVY Y. 1978: The distance and nature of the light trap response of moths. Nature 276: 818-821.

Boggs C.L. \& Murphy D.D. 1997: Community composition in mountain ecosystems: climatic determinants of mountain butterfly distributions. Global Ecol. Biogeog. 6: 39-48.

Brandmayr P., Mingozzi T., Scalercio S., Passalacqua N., Rotondaro F. \& Pizzolotto R. 2002: Stipa austroitalica garigues and mountain pastureland in the Pollino National Park (Calabria, Southern Italy). In Redecker B., Finck P., Härdtle W., Riecken U. \& Schröder E. (eds): Pasture Landscapes and Nature Conservation. Springer, Berlin, Heidelberg, pp. 53-66.

Brunetti M., Maugeri M., Fabio M. \& Nanni T. 2006: Temperature and precipitation variability in Italy in the last two centuries from homogenised instrumental time series. Int. J. Climatol. 26: 345-381.

BÜRGER R. \& LYNCH M. 1995: Evolution and extinction in a changing environment: a quantitative genetic analysis. Evolution 49: 151-163.

Colwell R.K. 2005: EstimateS: Statistical estimation of species richness and shared species from samples. Version 7.5. [internet]. Storrs (CT): Robert K. Colwell; (Cited 2008 Feb 20). Available from: http://viceroy.eeb.uconn.edu/estimates

Gotelli N.J. \& Colwell R.K. 2001: Quantifying biodiversity: procedures and pitfalls in the measurement and comparison of species richness. Ecol. Lett. 4: 379-391.

Grabherr G., Gottfried M. \& Pauli H. 1994: Climate effects on mountain plants. Nature 369: 448.
Hanski I. \& Ovaskainen O. 2000: The metapopulation capacity of a fragmented landscape. Nature 404: 755-758.

Hausmann A. 2002: The Geometrid Moths of Europe. Vol. 1. Apollo Books, Stenstrup, $282 \mathrm{pp}$.

Hickling R., Roy D.B., Hill J.K., Fox R. \& Thomas C.D. 2006: The distributions of a wide range of taxonomic groups are expanding polewards. Glob. Change Biol. 12: 450-455.

Hilbert D., Bradford M., Parker T. \& Westcott D.A. 2004: Golden bowerbird (Prionodura newtoniana) habitat in past, present and future climates: predicted extinction of a vertebrate in tropical highlands due to global warming. Biol. Conserv. 116: 367-377.

Holdhaus K. 1954: Die Spuren der Eiszeit in der Tierwelt Europas. Universitätsverlag Wagener, Innsbruck, $493 \mathrm{pp}$.

HOYLE M. \& JAMES M. 2005: Global warming, human population pressure, and viability of the world's smallest butterfly. Conserv. Biol. 19: 1113-1124.

Intergovernmental Panel on Climate Change. Fourth AssessMent Report 2007: Climate Change 2007: Synthesis Report. Summary for Policymakers [internet]. [cited 2008 Feb 20]. Available from: http://www.ipcc.ch/pdf/assessment-report/ ar4/syr/ar4_syr_spm.pdf

Kitching R.L., ORR A.G., Thalib L., Mitchell H., Hopkins M.S. \& Graham A.W. 2000: Moth assemblages as indicators of environmental quality in remnants of upland Australian rain forest. J. Appl. Ecol. 37: 284-297.

KonvičKa M., Maradová M., Beneš J., Fric Z. \& KepKa P. 2003: Uphill shifts in distribution of butterflies in the Czech Republic: effects of changing climate detected on a regional scale. Global Ecol. Biogeogr. 12: 403-410.

Magurran A.E. 1988: Ecological Diversity and its Measurement. Croom Helm, London, 192 pp.

Merrill R.M., Gutiérrez D., Lewis O.T., Gutiérrez J., D’ez S.B. \& Wilson R.J. 2007: Combined effects of climate and biotic interactions on the elevational range of a phytophagous insect. J. Anim. Ecol. 77: 145-155.

NEW T.R. 2004: Moths (Insecta: Lepidoptera) and conservation: background and perspective. J. Insect Conserv. 8: 79-94.

PARENZAN P. 1979: Contributi alla conoscenza della lepidotterofauna dell'Italia meridionale. V. Heterocera: Noctuidae. Entomologica 15: 159-278.

Parenzan P. \& Porcelli F. 2006: I Macrolepidotteri italiani. Fauna Lepidopterorum Italiae (Macrolepidoptera). Phytophaga, Riv. Entomol. Acarol. Mediter. 15: 5-391.

Parmesan C., Ryrholm N., Stefanescu C., Hill J.K., Thomas C.D., Descimon H., Huntley B., Kaila L., Kullberg J., Tammaru T., Tennent W.J., Thomas J.A. \& Warren M. 1999: Poleward shifts in geographical ranges of butterfly species associated with regional warming. Nature 399: 579-583.

Peñuelas J., Ogaya R., Boada M. \& Jump A.S. 2007: Migration, invasion and decline: changes in recruitment and forest structure in a warming-linked shift of European beech forest in Catalonia (NE Spain). Ecography 30: 829-837.

Pounds J.A., Fogden M.P. \& CAmpbell J.H. 1999: Biological responses to climate change on a tropical mountain. Nature 398: 611-615.

Racheli T., Prola C. \& Provera P. 1978: Note su alcuni Lepidotteri dell'Italia centrale. Boll. Assoc. Rom. Entomol. 33: 19-39.

Raineri V., Trematerra P. \& Zilli A. 1992: Notizie sulla cenosi lepidotterologica d'altitudine del Gran Sasso d'Italia (Lepidoptera). Boll. Assoc. Rom. Entomol. 46: 57-63.

Roy D.B. \& Sparks T.H. 2000: Phenology of British butterflies and climate change. Glob. Change Biol. 6: 407-416.

SCAlercio S. 2008: Novità faunistiche per il Parco Nazionale del Pollino. Boll. Soc. Entomol. Ital. 140: 115-120. 
Scalercio S., Pizzolotto R. \& Brandmayr P. 2007: Multi-scale analysis of butterfly diversity in a Mediterranean mountain landscape: mapping and evaluation of community vulnerability. Biodiv. Conserv. 16: 3463-3479.

SCAlercio S., Infusino M. \& Tuscano J. 2008: I macrolepidotteri notturni della faggeta di Monte Curcio, Sila Grande (Calabria, Italia meridionale) (Lepidoptera). Quad. Staz. Ecol. Civ. Mus. Stor. Nat. Ferrara 18: 5-19.

Sekercioglu C.H., Schneider S.H., Fay J.P. \& Loarie S.R. 2008: Climate change, elevational range shifts, and bird extinctions. Conserv. Biol. 22: 140-150.

Skelly D.K., Joseph L.N., Possingham H.P., Freidenburg L.K., Farrugia T.J., Kinnison M.T. \& Hendry A.P. 2007: Evolutionary responses to climate changes. Conserv. Biol. 21: $1353-1355$.

Stefanescu C., Herrando S. \& Páramo F. 2004: Butterfly species richness in the north-west Mediterranean Basin: the role of natural and human-induced factors. J. Biogeogr. 31: 905-915.

TAMANINI L. 1961: Ricerche zoologiche nel Massiccio del Pollino (Lucania-Calabria). XXX. Emitteri Eterotteri (Hemiptera Heteroptera). Annuar. Ist. Mus. Zool. Univ. Napoli 13: 1-128.

Thomas C.D., Cameron A., Green R.E., Bakkenes M., Beaumont L.J., Collingham Y.C., Erasmus B.F.N., Ferreira DE Siqueira M., Grainger A., Hannah L., Hughes L., Huntley B., van JaArsveld A.S., Midgley G.F., Miles L., OrtegaHuerta M.A., Townsend Peterson A., Phillips O.L. \& WilLIAMS S.E. 2004: Extinction risk from climate change. Nature 427: $145-148$.
Usher M.B. \& KeILLER S.W.J. 1998: The macrolepidoptera of farm woodlands: determinants of diversity and community structure. Biodiv. Conserv. 7: 725-748.

VirTANen T. \& NeUvonen S. 1999: Climate change and macrolepidopteran biodiversity in finland. Chemosphere 1: 439-448.

Warren M.S., Hill J.K., Thomas J.A., Asher J., Fox R., Huntley B., Roy D.B., Telfer M.G., Jeffcoate S., Harding P., Jeffcoate G., Willis S.G., Greatorex-Davies J.N., Moss D. \& Thomas C.D. 2001: Rapid responses of British butterflies to opposing forces of climate and habitat change. Nature 414: 65-69.

Weiss S.B., Murphy D.D. \& White R.R. 1988: Sun, slope, and butterflies: Topographic determinants of habitat quality for Euphydryas editha bayensis. Ecology 69: 1486-1496.

Williams S.E., Bolitho E.E. \& Fox S. 2003: Climate change in Australian tropical rainforest: an impending environmental catastrophe. Proc. R. Soc. Lond. (B) (Biol.) 270: 1887-1892.

Wilson R.J., Gutiérrez D., Gutiérrez J., Martinez D., Agudo R. \& MonserRat V.J. 2005: Changes to the elevational limits and extent of species ranges associated with climate change. Ecol. Lett. 8: 1138-1146.

Wilson R.J., Gutiérrez D., Gutiérrez J. \& Monserrat V.J. 2007: An elevational shift in butterfly species richness and composition accompanying recent climate change. Glob. Change Biol. 13: 1873-1887.

ZAKHAROV E.V. \& HellmanN J.J. 2008: Genetic differentiation across a latitudinal gradient in two co-occurring butterfly species: revealing population differences in a context of climate change. Mol. Ecol. 17: 189-208.

Received October 16, 2008; revised and accepted December 17, 2008 